\title{
SLAUGYTOJŲ ŽINIOS IR İŪDŽIAI ATLIEKANT SEKRETO IŠSIURBIMĄ IŠ TRACHEOSTOMOS VAMZDELIO
}

\author{
Alina Vaškelytė ${ }^{1,2}$, Silva Kostyliovienè ${ }^{1,4}$, Dovilè Grinkevičiūtè $\dot{e}^{3,4}$ \\ ${ }^{1}$ Kauno kolegijos Medicinos fakulteto Slaugos katedra, ${ }^{2}$ Lietuvos sveikatos mokslo universiteto \\ Medicinos akademijos Slaugos ir rüpybos katedra, ${ }^{3}$ Lietuvos sveikatos mokslu universiteto \\ Medicinos akademijos Medicinos fakulteto Vaiku ligu klinika, \\ ${ }^{4}$ Lietuvos sveikatos mokslu universiteto ligoninès Vaiku intensyviosios terapijos skyrius
}

Raktažodžiai: slaugytojų žinios ir ịūdžiai, sekreto išsiurbimas iš tracheostomos vamzdelio, tracheostomos priežiūra.

\section{Santrauka}

Siekiant sumažinti skyriuose slaugomiems pacientams, kuriems išvesta tracheostoma, priežiūros sukeltų komplikacijų skaičiu, labai svarbu, kad slaugytojai sekreto išsiurbimo iš tracheostomos vamzdelio procedūrą atliktų saugiai ir veiktų vadovaudamiesi moksliniais tyrimais pagrịstomis rekomendacijomis. Šio tyrimo tikslas buvo išanalizuoti slaugytojų žinias ir igūdžius atliekant sekreto išsiurbimą iš tracheostomos vamzdelio. Tyrimas vyko Kauno miesto ligoninių skyriuose, ị kuriuos tracheostomuoti pacientai dažniausiai patenka iš Intensyviosios terapijos skyrių. Pirmojo tyrimo etapo metu buvo vykdoma slaugytojų anketiné apklausa, antrojo - slaugytoju praktikinių veiksmų, atliekant sekreto išsiurbimą iš tracheostomos vamzdelio, stebejimas. Anketinèje apklausoje dalyvavo 93 slaugytojai, buvo stebètos 99 sekreto išsiurbimo iš tracheostomos vamzdelio procedūros. Tyrimo duomenims rinkti buvo naudojama autorių sukurta Slaugytojų žinių nustatymo anketa ir Slaugytojų praktikinių veiksmų stebėjimo protokolas.

Rezultatai. Registruojant požymius, rodančius sekreto išsiurbimo iš tracheostomos vamzdelio poreikị, dažniausiai buvo stebimas paciento kosulys $(77,8$ proc.), apie pusės stebėtų atvejų metu melsvèjo paciento veidas ir lūpos $(42,4$ proc.). Apklausos metu 81,0 proc. slaugytojų nurodè, kad sekretą siurbia, kai pacientas kosejja ir 52,4 proc. - kai pacientas pats paprašo (lyginant su stebejj. $\chi^{2}=64,681 ; 1 l s=1 ; \mathrm{p}<0,001$ ). Daugiau nei pusė respondentų $(59,1$ proc.) teigè, kad siurbia sekretą iš tracheostomos vamzdelio, kai melsvejja paciento lūpos, veidas, tačiau buvo stebèta statistiškai reikšmingai mažiau atvejų, kai buvo atliekamas atsiurbimas melsvejjant paciento lūpoms, veidui $(42,4$ proc.; lyginant su apklausa $\left.\chi^{2}=5,315 ; 11 \mathrm{~s}=1 ; \mathrm{p}=0,021\right)$. Daugelio ( 88,9 proc.) stebètų procedūrų metu buvo naudojamas didesnis nei $150 \mathrm{mmHg}$ sekreto siurbimo slègis. Anketinès apklausos metu daugiau nei pusė (60,1 proc.) slaugytojų nurodè, kad siurbia tokiu slégiu, koks yra nustatytas siurblyje. Penktadalis (20,2 proc.) slaugytojų nurodè, kad prieš siurbiant sekretą iš tracheostomos vamzdelio, pirmiausia išsiurbtų sekretą iš burnos ir nosiaryklès. Stebejjimo metu gauti panašūs rezultatai (19,2 proc.). Beveik pusė (46,7 proc.) slaugytojų žinojo ir tai atliko praktikoje (45,5 proc.), kad vienkartinio kateterio ịleidimo ir sekreto išsiurbimo trukmé turi būti iki 15 sek. Anketinès apklausos metu dauguma (94,9 proc.) slaugytojų nurodé, kad procedūros metu ịpila ị tracheostomos vamzdelị sterilaus sol. $\mathrm{NaCl} 0,9$ proc. tirpalo, tačiau stebejjimų metu tai registravome statistiškai reikšmingai rečiau $(9,3$ proc. lyginant su stebej. $\left.\chi^{2}=138,857 ; 11 s=1 ; p<0,001\right)$. Išvados. Didžioji dalis slaugytojų teisingai žinojo požymius, rodančius sekreto iš tracheostomos vamzdelio išsiurbimo poreikị bei sekreto išsiurbimo trukmę. Klinikinejje praktikoje slaugytojai tinkamai taikè turimas žinias apie sekreto iš tracheostomos vamzdelio išsiurbimo poreiki bei sol. $\mathrm{NaCl} 0,9$ proc. tirpalo naudojimą. Apie pusė apklaustųjų slaugytojų neteisingai nurodė siurbimo veiksmų seką ir siurbimo slègị. Stebejjimų metu didžioji dalis slaugytojų sekreto siurbimo metu veiksmus atliko neteisinga seka, apie pusès stebètų atvejų metu buvo siurbiama per dideliu slègiu ir per ilgai. 


\section{Ivadas}

Tracheostoma atliekama pacientams siekiant užtikrinti kvejpavimo takų praeinamumą ir esat reikalingai ilgalaikei ventiliacijai [1]. Gali būti kelios priežastys, dèl kurių atliekama ši procedūra $[2,3]$. Dažniausiai tracheostoma atliekama, kai reikalinga ilgalaikè dirbtinè plaučių ventiliacija, siekiant užtikrinti kvẻpavimo takų atvirumą ar išvengti aspiracijos pacientams, patyrusiems galvos smegenų traumą ar esant neurologiniams pažeidimams [4]. Daliai pacientuc vèliau tracheostoma uždaroma, o tie pacientai, kuriems reikalinga ilgalaikè tracheostoma, tačiau kvejpuoja patys per tracheostomos vamzdelį, iškeliami iš Intensyviosios terapijos skyriaus (ITS) ị kitus skyrius ar kitų ligoninių stacionaro ar reabilitacijos skyrius [5]. Slaugytojai, slaugydami toki pacientą, privalo turèti žinių ir ịgūdžių, siekiant užtikrinti saugias ir veiksmingas sveikatos priežiūros paslaugas $[6$, 7]. Paul F. (2010) teigia, kad slaugytojai gali patirti nerimą ar stresą, kai rūpinasi perkeltu iš ITS pacientu su tracheostoma [6]. Slaugytojams, slaugant pacientą su tracheostoe mos vamzdeliu, tenka atlikti sekreto išsiurbimą vakuumo pagalba iš tracheostomos vamzdelio. Tai efektyvus būdas, norint išlaikyti kvépavimo takų praeinamumą [8-10]. Tracheostomos priežiūros veiksmai bei sekreto išsiurbimo iš tracheostomos vamzdelio technika gali paveikti komplikacijų dažnumą [11], kas gali lemti paciento saugumą, pasveikimo galimybę, gydymo trukmę bei gydymo kainą [11, 12]. Danijoje [13], Olandijoje [14] atlikti tyrimai atskleide, kad labai trūksta gairių, kuriomis būtų galima vadovautis, prižiūrint ị skyrių iš ITS perkeltą pacientą su tracheostomos vamzdeliu. Siekiant sumažinti skyriuose slaugomiems pacientams priežiūros sukeltų komplikacijų skaičių, labai svarbu, kad slaugytojai atliktų procedūrą saugiai ir veiktų vadovaudamiesi moksliniais tyrimais pagristomis rekomendacijomis $[2,8,9]$. Tai leistų slaugytojams priimti pagrịstus sprendimus dèl tracheostomos priežiūros ir sekreto išsiurbimo veiksmų, remiantis paciento individualiais poreikiais. Siekiant užtikrinti ir gerinti tracheostomos priežiūros teikiamų paslaugų kokybę, slaugytojams būtinos geros teorinès žinios ir praktiniai igūdžiai, pagrịsti moksliniais tyrimais $[15,16]$. Slaugytojas turi tureti pakankamai kompetencijos nuspręsti apie sekreto išsiurbimo iš tracheostomos vamzdelio būtinumą. Užsienio šalyse atlikti tyrimai rodo, kad slaugytojai, atlikdami tracheostomos priežiūrą, ne visada remiasi ịrodymais pagrịsta praktika [17-21]. Day T., Iles N., Griffiths P. (2009) teigimu, nepakanka ịvertinti slaugytojų teorines žinias, nes jos gali prastai atspindèti praktiką [19]. Todèl šio tyrimo metu buvo siekiama sužił noti, kokios yra slaugytojų žinios apie tracheostomos priežiūrą ir nustatyti, ar turimos žinios taikomos klinikinejje praktikoje.
Darbo tikslas: išanalizuoti slaugytojų žinias ir ịgūdžius atliekant sekreto išsiurbimą iš tracheostomos vamzdelio.

\section{Tyrimo medžiaga ir metodai}

Tyrimas vyko $2013 \mathrm{~m}$. Kauno miesto ligoninių skyriuose, i kuriuos tracheostomuoti pacientai dažniausiai patenka iš Intensyviosios terapijos skyrių (ITS). Dalyvauti tyrime buvo pakviesti visi 111 tuose skyriuose dirbančiu slaugytojų. Tyrimas buvo vykdomas etapais: 1) Slaugytojų anketinè apklausa; 2) slaugytojų praktikinių veiksmų, atliekant sekreto išsiurbimą iš tracheostomos vamzdelio, stebejimas.

Anketineje apklasoje sutiko dalyvauti ir buvo išdalintos 93 anketos, iš kurių grịžo ir tinkamos analizei buvo 84, atsako dažnis - 96,77 proc. Buvo stebėtos 99 sekreto išsiurbimo iš tracheostomos vamzdelio procedūros, stebejjimu trukme buvo 60 val. $40 \mathrm{~min}$.

Pagal amžių 9,5 proc. respondentų priklausè jaunesnių nei $29 \mathrm{~m}$. grupei; 30 - $39 \mathrm{~m}$. amžiaus grupei priklausė 21,4 proc.; $40-49 \mathrm{~m}$. amžiaus grupei - 38,1 proc. ir vyresnių nei 50 m. - 31,0 proc. tiriamuju. Daugiau nei pusè (69,0 proc.) respondentų išsimokslinimą igijo medicinos mokyklose; beveik penktadalis (17,8 proc.) turèjo aukštaji neuniversitetinị ir dešimtadalis (11 proc.) aukštajį universitetinị išsimokslinimą. Didžioji dalis respondentų ( 76,2 proc.) turejjo daugiau nei dešimties metų, 10,7 proc. - nuo šešerių iki dešimties ir 13,1 proc. - mažiau nei penkerių metų klinikinio darbo patirti.

Tyrimas atliktas naudojant autorių sukurtą Slaugytojųžinių nustatymo anketą, kurią sudare 31 klausimas. Slaugytojų praktikiniai veiksmai atliekant sekreto išsiurbimą iš tracheostomos vamzdelio buvo registruojami Slaugytojų praktikinių veiksmų stebėjimo protokole, parengtame autorių.

Rezultatų analizei ir duomenų pateikimui buvo naudota aprašomosios statistikos skaitinès charakteristikos: vidurkis, standartinis nuokrypis, pasiskirstymas dažniais pateikiamas procentine išraiška. Esant nenormaliam pasiskirstymui tarp dviejų grupių, buvo taikomas Mann - Whitney testas, o esant daugiau nei dviem grupėms - Kruskal - Wallis testas. Esant normaliam pasiskirstymui tarp dviejų grupių, buvo taikomas $\mathrm{T}$ testas arba Stjudent'o testas, kai grupiu buvo daugiau nei dvi - ANOVA testas. Kokybinių požymių statistinis ryšys buvo tiriamas susietų lentelių metodu. Remiantis lentelių duomenimis, apskaičiuota chi kvadrato $\left(\chi^{2}\right)$ reikšmé, laisvès laipsnių skaičius (lls), rezultatai laikyti statistiškai patikimais, kai statistinio reikšmingumo koeficientas $\mathrm{p}<0,05$. Anketos išorinis patikimumas vertintas, taikant testo-testą (test-retest) ir McNemar testą. Koreliacinè analizè atlikta atliekant testo-testą.

Tyrimui atlikti buvo gautas LSMU Bioetikos centro pritarimas Nr. BEC-KS (M)-198. 


\section{Rezultatai}

Atliekant sekreto išsiurbimą iš tracheostomos vamzdelio visais (100 proc.) stebėtais atvejais sekretą siurbė vienas slaugytojas, tai patvirtino ir apklausos rezultatai.

Registruojant požymius, rodančius sekreto išsiurbimo iš tracheostomos vamzdelio poreikį, dažniausiai buvo stebimas paciento kosulys (77,8 proc.), apie pusès stebètu atvejų metu melsvejjo paciento veidas ir lūpos (42,4 proc.), tik mažos dalies ( 1,0 proc.) procedūrų metu pacientai patys paprašè išsiurbti sekretą iš tracheostomos vamzdelio.

Apklausos metu didžioji dalis slaugytojų ( 81,0 proc.) nurodé, kad sekretą siurbia, kai pacientas kosèja ir daugiau nei pusè slaugytojų nurodè, kad siurbia sekretą iš tracheostomos vamzdelio, kai pacientas pats paprašo $(52,4$ proc. lyginant su stebejj. $\left.\chi^{2}=64,681 ; 11 s=1 ; p<0,001\right)$.

Daugiau nei pusè respondentų $(59,1$ proc.) teigè, kad siurbia sekretą iš tracheostomos vamzdelio, kai melsvèja paciento lūpos, veidas, tačiau buvo stebèta statistiškai reikšmingai mažiau atvejų, kai buvo atliekamas atsiurbimas melsvejjant paciento lūpoms, veidui $(42,4$ proc.; lyginant su apklausa $\left.\chi^{2}=5,315 ; 11 \mathrm{~s}=1 ; \mathrm{p}=0,021\right)$ ( $1 \mathrm{pav}$.).

Tik apie dešimtadalio (11,1 proc.) stebètų procedūrų atveju slaugytojai siurbè sekretą, kai nebuvo stebimi jokie požymiai, rodantys sekreto siurbimo poreikį, tuo tarpu anketinès apklausos metu statistiškai reikšmingas didesnè dalis $\left(34,5\right.$ proc. lyginant su stebejj. $\left.\chi^{2}=14,584 ; 11 s=1 ; p<0,001\right)$ slaugytojų nurodè, kad ịprasta rutiniškai atlikti siurbimus kas kelias valandas.

Registruojant siurbimo slègi daugelio ( 88,9 proc.) stebètų procedūrų metu buvo naudojamas didesnis nei 150 $\mathrm{mmHg}$ sekreto siurbimo slègis. Anketinès apklausos metu daugiau nei pusè $(60,1$ proc.) slaugytojų nurodè, kad siurbia tokiu slègiu, koks yra nustatytas siurblyje ir daugiau nei dešimtadalis (11,9 proc.) - didžiausiu slègiu, esančiu siurbly-

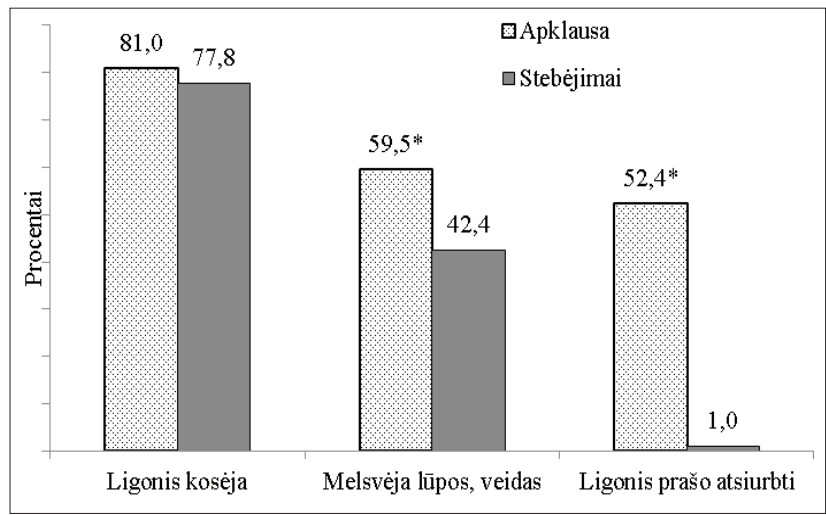

1 pav. Požymiai, rodantys sekreto siurbimo iš tracheostomos vamzdelio poreiki

$* p<0,05$ lyginant su stebejjimais je. Didžiosios dalies (86,9 proc.) stebèjimų metu buvo registruotas didesnis nei $150 \mathrm{mmHg}$ siurbimo slègis (2 pav.).

Penktadalis (20,2 proc.) apklausoje dalyvavusių slaugytojų nurodè, kad prieš siurbiant sekretą iš tracheostomos vamzdelio, pirmiausia išsiurbtų sekretą iš burnos ir nosiaryklès. Stebejjimo metu buvo gauti panašūs rezultatai (19,2 proc.). Atliekant procedūras beveik penktadalis (19,2 proc.) slaugytojų prieš siurbiant sekretą iš tracheostomos vamzdelio, išsiurbė sekretą iš burnos ir nosiaryklès.

Didžioji dalis respondenčiu teigè, kad pasikeičia pirštines po sekreto išsiurbimo iš burnos ir nosiaryklès, prieš siurbiant iš tracheostomos vamzdelio, tačiau stebejimų metu tai darè tik nedidelè dalis $(8,1$ proc.) slaugytojų $\left(\chi^{2}=153,585 ; 11 \mathrm{~s}=1 ; \mathrm{p}<0,001\right)$

Anketinès apklausos metu dauguma (94,9 proc.) slaugytojų nurode, kad procedūros metu ịpila ị tracheostomos vamzdeli sterilaus sol. $\mathrm{NaCl} 0,9$ proc. tirpalo, tačiau stebėjimų metu tai registravome statistiškai reikšmingai rečiau $(9,3$ proc. lyginant su stebejj. $\left.\chi^{2}=138,857 ; 11 \mathrm{~s}=1 ; \mathrm{p}<0,001\right)$ ( 3 pav).

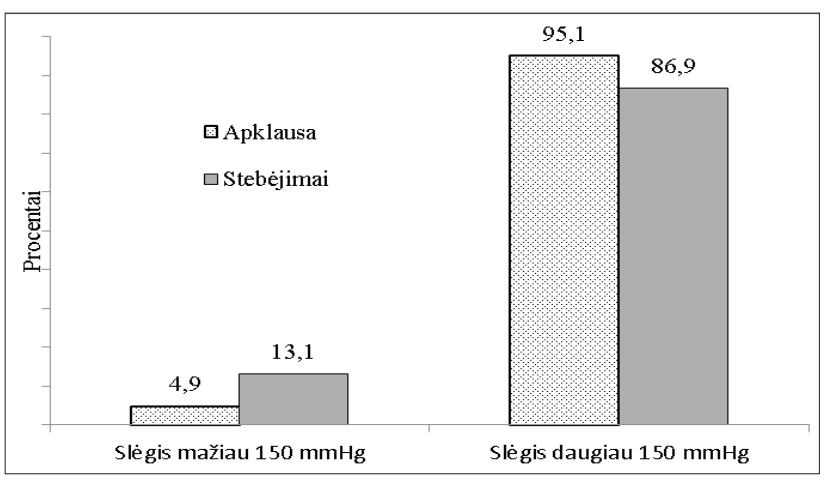

2 pav. Slejgis, kuriuo siurbiamas sekretas iš tracheostomos vamzdelio

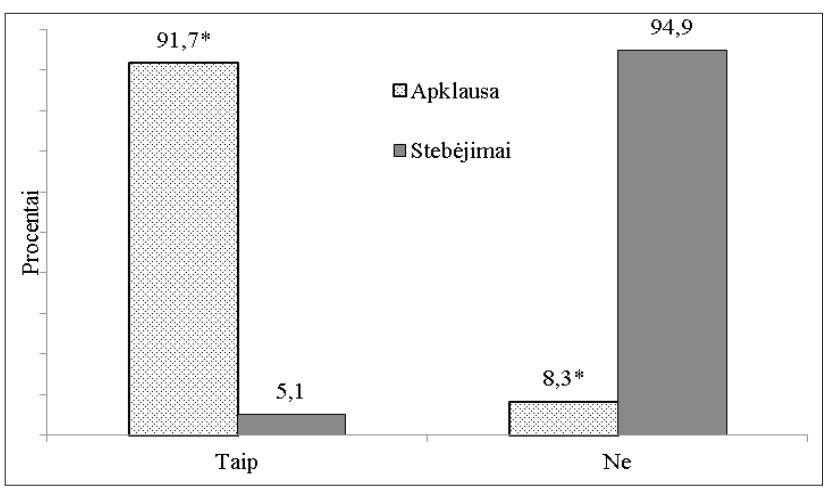

3 pav. Sekreto išsiurbimo metu sterilaus sol. $\mathrm{NaCl} 0,9$ proc. tirpalo ipylimas i tracheostomos vamzdelį: anketinès apklausos ir stebejjimų duomenų palyginimas

$* p<0,05$ lyginant su stebejimais 
Daugiau nei trečdalio (39,3 proc.) stebėtų procedūrų metu slaugytojai atsiurbimo kateterị i vamzdeli ịkišo nesiurbdami. Anketinès apklausos metu beveik pusè (46,7 proc.) slaugytojų nurodè, kad vienkartinio kateterio įleidimo ir sekreto išsiurbimo laikas turi būti iki 15 sek. Stebejjimų metu taip pat beveik pusès (45,5 proc.) procedūrų metu vienkartinio kateterio ileidimas i tracheostomos vamzdeli ir sekreto išsiurbimas truko iki 15 sek.

Atliekant stebėjimus beveik ketvirtadalio (24,4 proc.) stebètų sekreto išsiurbimo procedūrų metu pakako vieno sekreto išsiurbimo epizodo, kurio metu buvo sunaudotas vienas atsiurbimo kateteris. Daugiau nei pusès $(54,4$ proc.) stebètų procedūrų metu atsiurbimo kateteris buvo pakartotinai ịkišamas ị tracheostomos vamzdelį, tuo tarpu apklausos metu daugiau nei pusè (54,8 proc.) slaugytojų nurodè, kad sekreto atsiurbimo iš tracheostomos vamzdelio metu sunaudoja vieną atsiurbimo kateterị.

\section{Diskusija}

Tyrimo metu buvo siekiama išsiaiškinti, kokios yra slaugytojų žinios apie sekreto išsiurbimą iš tracheostomos vamzdelio, ar jos atitinka moksliniais tyrimais pagrịstas rekomendacijas, kaip ši procedūra atliekama klinikinejje praktikoje.

Kelleher S., Andrews T. (2008) atliktų tyrimų praktinių veiksmų stebejjimo metu buvo nustatyta, kad slaugytojai prieš endotrachejjini sekreto siurbimą neišklausè kvèpavimo garsų plaučiuose, o sekreto siurbimą atliko dažnai esant vienam požymiui, rodančiam siurbimo poreikị [20]. Lietuvoje nèra iprasta, kad slaugytojai auskultuotų pacientų plaučius ir pagal tai vertintų, ar reikalingas sekreto išsiurbimas iš tracheostomos vamzdelio, tai atlieka gydytojai. Stebejjimo rezultatai parodè, kad praktikoje dauguma slaugytojų sekretą siurbė esant sekreto siurbimo poreikiui. Tik dešimtadalyje stebètu sekreto išsiurbimo iš tracheostomos vamzdelio procedūrų atvejų slaugytojai siurbè sekretą, kai nebuvo stebimi jokie požymiai, rodantys sekreto išsiurbimo poreikį. Siekiant išvengti sekreto, esančio virš tracheostomos vamzdelio manžetès ịtekejjimo ị apatinius kvejpavimo takus, rekomenduojama prieš sekreto siurbimą iš tracheostomos vamzdelio išsiurbti sekretą iš burnos ir nosiaryklès [16, 22, 23].

Mūsų atlikto tyrimo metu dauguma slaugytojų nurodè, kad tai atlieka priešinga seka: pirmiausia sekretą siurbia iš tracheostomos vamzdelio, po to iš burnos ir nosies.

Suomijoje (2012) atlikto ITS tyrimo metu tik truputi daugiau nei dešimtadalyje (15 proc.) stebètų atvejų siurbimo sleggis buvo $80-150 \mathrm{mmHg}$ [21]. Airijoje (2008) atlikto tyrimo metu sekreto siurbimo slègiai viršijo rekomenduojamus slègius ir svyravo 230 - $450 \mathrm{mmHg}$ [20]. Lietuvoje
(2013) atlikto tyrimo metu, ITS skyriuose stebint praktinius veiksmus buvo registruotas sekreto išsiurbimo tracheostominio vamzdelio slègis: mažiausias slègis $100 \mathrm{~mm} /$ $\mathrm{Hg}$, didžiausias $525 \mathrm{~mm} / \mathrm{Hg}$. Sekreto išsiurbimo slègio ITS vidurkiai svyravo nuo $107,3 \mathrm{~mm} / \mathrm{Hg}$ ir daugiau nei $310 \mathrm{mmHg}$ [24]. Mūsų atlikto tyrimo rezultatai buvo labai panašūs: stebejimo metu daugelyje stebėtu atvejų buvo registruotas didesnis nei $150 \mathrm{mmHg}$ slègis, o didžiausias stebejjimų metu registruotas slègis buvo $-600 \mathrm{mmHg}$. Praktikoje naudojami dideli siurbimo slègiai kelia susirūpinimą, kadangi siurbiant per dideliu slègiu didèja plaučių pažeidimo bei sekreto, esančio virš manžetès, ịtekèjimo ị trachèją rizika [25].

Lietuvoje (2013) atlikto tyrimo autoriai nurodo, kad anketineje apklausoje beveik visi respondentai siurbia ne ilgiau kaip 15 sek., tačiau stebint praktinius veiksmus buvo fiksuojami atskiri atvejai, kai sekreto išsiurbimas trunka 25 - 40 sek. [24]. Šio tyrimo metu klinikineje praktikoje apie pusè stebètų atvejų sekreto išsiurbimo trukmė buvo ilgesnè nei 15 sek., o Airijoje (2008) atlikto tyrimo metu né vienas slaugytojas nesiurbè ilgiau nei 15 sek. [20].

Mūsų tyrimo praktikinių veiksmų stebëjimo rezultatai buvo labai panašūs ị kitų mokslininkų atliktų tyrimų rezultatus, kurie atskleidè, kad slaugytojų žinios ne visada atitinka mokslines rekomendacijas ir skiriasi nuo klinikinès praktikos veiksmų [20, 26]. Šio tyrimo praktikinių veiksmų stebejimo metu registravome, kad nebuvo siurbiamas sekretas iš burnos ir nosiaryklès prieš sekreto išsiurbimą iš tracheostomos vamzdelio, apie pusę stebetų atvejų buvo pakartotinai ikišamas tas pats atsiurbimo kateteris i tracheostomos vamzdelį. Galima daryti prielaidą, kad tai yra būdas taupyti lèšas, nes tada slaugytojai sekreto išsiurbimo iš tracheostomos vamzdelio metu sunaudoja tik vieną sekreto išsiurbimo kateterị. Tačiau tokiu atveju gerokai pailgejja vienkartinis sekreto išsiurbimo laikas ir didejja infekcijos bei sekreto, esančio virš vamzdelio manžetès, aspiracijos rizika. Praktinių veiksmų stebejjimo metu tai dare nedidele dalis slaugytojų, o po sekreto išsiurbimo iš burnos didelè dalis slaugytojų nepasikeite pirštinių, nors anketinès apklausos metu dauguma slaugytojų nurodè tai darantys.

Galima daryti prielaidą, kad slaugytojai po sekreto išsiurbimo iš burnos, prieš siurbdami iš tracheostomos vamzdelio, nepasikeičia pirštinių dèl didelio darbo krūvio, taupydami laiką ir priemones. Visi šie veiksniai gali didinti komplikacijų skaičių pacientams. Šio tyrimo praktinių veiksmų stebejjimo metu tik maža dalis slaugytojų siurbė sekretą rutiniškai, ịpyle ị tracheostomos vamzdeli sterilaus sol. $\mathrm{NaCl} 0,9$ proc. tirpalo

Atlikto tyrimo rezultatai atskleide problemines tracheostomos priežiūros sritis. Gauti rezultatai kelia susirūpini- 
mą, nes sekreto išsiurbimo metu nedidelè dalis slaugytojų vis dar rinkosi didelị sekreto siurbimo slègị ir ilgai siurbè sekretą, netaikè teisingos sekreto siurbimo veiksmų sekos. Todèl būtini pokyčiai atliekant tracheostomos priežiūrą, siekiant užtikrinti pacientų saugumą bei kokybišką slaugą. Kadangi Lietuvoje nèra patvirtinto vieningo tracheostomos priežiūros standarto, lieka didelè laisvè slaugytojams sekreto išsiurbimo procedūrą atlikti taip, kaip yra ịprasta jų darbo vietoje, o ne taip, kaip rekomenduoja ịrodymais pagrịsta slauga.

Mūsų atlikto tyrimo rezultatai parodè, kad ne visada slaugytojų turimos žinios buvo taikomos praktikoje. Manome, kad slaugytojams reikètų tobulinimosi kursų apie tracheostomos priežiūrą bei didesnị dèmesị būtų tikslinga skirti individualiam slaugytojų mokymui darbo vietoje. Woodrow P. (2002) teigè, kad tiems sveikatos priežiūros specialistams, kurie retai atlieka tracheostomos priežiūrą, yra labai svarbu tikslūs tracheostomos priežiūros dokumentai [17]. Klinikinejje praktikoje būtų tikslinga ịdiegti tracheostomos priežiūros standartą bei tracheostomos priežiūros sekimo lapus, kuriuose būtų visa slaugytojams reikalinga informacija apie pacientą ir jam suformuotą tracheostomą.

Šio tyrimo stiprioji pusè: tyrimo metu buvo taikoma duomenų trianguliacija, kai tarpusavyje buvo derinami ir lyginami anketinès apklausos ir slaugytojų praktinių veiksmų stebèjimo duomenys. Silpnosios pusès - tiriamujų imtis nebuvo didelè, o tyrimas buvo vykdomas tik Kauno miesto sveikatos priežiūros įstaigose. Ne visose tyrimo vietose galëjome stebėti praktinius veiksmus. Kadangi praktiniu veiksmų stebejjimas buvo atviras, išlieka Hawthorne efekto tikimybė, jog slaugytojai labiau stengèsi atlikti procedūrą pagal rekomendacijas, o kasdieninèje veikloje šią procedūrą atlieka kitaip, t.y. jiems ịprastai. Tokị fenomeną stebèjome ir mūsu tyrimo metu, kai pradžioje tyrimo tekdavo ilgiau laukti, kol slaugytojai atliks sekreto išsiurbimą iš tracheostomos vamzdelio (siurbdavo tada, kai atsirasdavo požymiai, rodantys, kad reikia sekretą išsiurbti), sunaudodavo daugiau nei vieną sekreto išsiurbimo kateterị.

\section{Išvados}

1. Didžioji dalis slaugytojų teisingai žinojo požymius, rodančius sekreto iš tracheostomos vamzdelio išsiurbimo poreikị bei sekreto išsiurbimo trukmę. Klinikinèje praktikoje slaugytojai tinkamai taikè turimas žinias apie sekreto iš tracheostomos vamzdelio išsiurbimo poreikị bei sol. $\mathrm{NaCl} 0,9$ proc. tirpalo naudojimą.

2. Apie pusė apklaustujų slaugytojų neteisingai nurodė siurbimo veiksmų seką ir siurbimo slègị. Stebejjimų metu didžioji dalis slaugytojų sekreto siurbimo metu veiksmus atliko neteisinga seka, apie pusės stebėtų atvejų metu buvo siurbiama per dideliu slègiu ir per ilgai.

\section{Literatūra}

1. De Leyn P, Bedert L, Delcroix M, Depuydt P, Lauwers G, Sokolov Y. et al. Tracheotomy: clinical review and guidelines. Eur J Cardiothorac Surg 2007; 32(3):412-421. http://dx.doi.org/10.1016/j.ejcts.2007.05.018

2. Morris LL, Whitmer A, McIntosh E. Tracheostomy care and complications in the intensive care unit. Critical Care Nurse 2013; 33(5): 18-30. http://dx.doi.org/10.4037/ccn2013518

3. Durbin CG. Tracheostomy: Why, When, and How? Respir Care 2010;55 (8): 1056-68.

4. Cheung NH, Napolitano LM. Tracheostomy: epidemiology, indications, timing, technique, and outcomes. Respir Care 2014 Jun;59(6):895-915.

http://dx.doi.org/10.4187/respcare.02971

5. Siera A. Tracheostomy care. Nursing Standard 2000;14(42):4552.

http://dx.doi.org/10.7748/ns2000.07.14.42.45.c2872

6. Paul F. Tracheostomy care and management in general wards and community settings: literature review. Nursing in critical 2010; 15(2):76-85.

http://dx.doi.org/10.1111/j.1478-5153.2010.00386.x

7. Regan EN, Dallachiesa L. How to care for a patient with a tracheostomy. Nursing 2009; 39(8):34-9.

http://dx.doi.org/10.1097/01.NURSE.0000358572.79112.bd

8. Björling G. Long-term tracheostomy care: How to do it? Breathe 2009; 5(3):204-213.

http://dx.doi.org/10.1183/18106838.0503.204

9. Freeman S. Care of adult patients with a temporary tracheostomy. Nursing Standard 2011; 26(2):49-56. http://dx.doi.org/10.7748/ns.26.2.49.s52

10. Higgins D. Basic nursing principles of caring for patients with a tracheostomy. Nurs Times 2009; 105(3) 14-15.

11. Wood C.J. Can nurses safely assess the need for endotracheal suction in short-term ventilated patients, instead of using routine techniques? Intensive Crit Care Nurs 1998;14(4):170-8. http://dx.doi.org/10.1016/S0964-3397(98)80486-2

12. Celik SA, Elbas NO. The standard of suction for patients undergoing endotracheal intubation. Intensive Crit Care Nurs 2000;16(3):191-8. http://dx.doi.org/10.1054/iccn.2000.1487

13. Mondrup F, Skjelsager K, Madsen KR. Inadequate follow-up after tracheostomy and intensive care. Dan Med J 2012;59(8):A4481.

14. Veelo DP, Schultz MJ, Phoa KY. et al. Management of tracheostomy: a survey of Dutch intensive care units. Respir Care 2008;53(12):1709-15. 
15. Standards for the Care of Adult Patients with a Temporary Tracheostomy. Standards and Guidelines. London: Council of the Intensive Care Society, 2008.

16. Woodrow P. Managing patients with a tracheostomy in acute care. Nursing Standard 2002;16 (44) 39-46. http://dx.doi.org/10.7748/ns.16.44.39.s14

17. Akram Ansari, Negin Masoudi Alavi, Mohsen Adib Hajbagheri. et al. The gap between knowledge and practice in standard Endo-tracheal suctioning of ICU nurses, Shahid Beheshti Hospital. Iran J Crit Care Nurs 2012;5(2):71-76.

18. Day T, Farnell S, Haynes S. et al. Tracheal suctioning: an exploration of nurses' knowledge and competence in acute and high dependency ward areas. J Adv Nurs 2002;39(1):35-45. http://dx.doi.org/10.1046/j.1365-2648.2002.02240.x

19. Day T, Iles N, Griffiths P. Effect of performance feedback on tracheal suctioning knowledge and skills: randomized controlled trial. J Adv Nurs 2009;65(7):1423-1431.

http://dx.doi.org/10.1111/j.1365-2648.2009.04997.x

20. Kelleher S, Andrews T. An observational study on the opensystem endotracheal suctioning practices of critical care nurses. J Clin Nurs 2008;17(3): 360-9. http://dx.doi.org/10.1111/j.1365-2702.2007.01990.x

21. Miia Jansson, Tero Ala-Kokko, Pekka Ylipalosaari. et al. Evaluation of endotracheal - suctioning practices of critical-care nurses-An observational correlation study. Journal of Nursing Education and Practice 2013 3(7):99-105.

http://dx.doi.org/10.5430/jnep.v3n7p99

22. American Association for Respiratory care. Clinical Practice Guidelines. Endotracheal suctioning of mechanically ventilated patients with artificial airways 2010. Respir Care 2010; 55(6): 758-764.

23. Lorente L, Blot S, Rello J. New issues and controversies in the prevention of ventilator-associated pneumonia. American Journal of Respiratory and Critical Care Medicine 2010; 182(7):870-876.

http://dx.doi.org/10.1164/rccm.201001-0081CI

24. Kostyliovienė S., Demskytė J. Sekreto išsiurbimo iš tracheostominio vamzdelio ịvertinimas. Slaugos studijų, mokslo ir praktikos integracija: pažanga praktikai: XII respublikiné slaugytojų konferencija Tarptautinei slaugytojų dienai paminèti: konferencijos tezès, 2013 m. gegužès 9 d., Kaunas, 2013; 21-23.

25. Dave MH, Frotzler A, Madjdpour C. et al. Massive aspiration past the tracheal tube cuff caused by closed trachael suction system. J Intensive Care Med 2011;26: 326-329.

http://dx.doi.org/10.1177/0885066610392516
26. Özden D, Görgülü RS. Development of standard practice guidelines for open and closed system suctioning. J Clin Nurs 2012;21(9-10):1327-38.

http://dx.doi.org/10.1111/j.1365-2702.2011.03997.x

\section{NURSES' KNOWLEDGE AND SKILLS IN TECH- NIQUE OF SECRETION SUCTIONING FROM TRA- CHEOSTOMY TUBE}

A. Vaškelytė, S. Kostyliovienė, D. Grinkevičiūtė

Key words: nurses' knowledge and skills, secretion suctioning from tracheostomy tube, tracheostomy care.

Summary

Technique of secretion suctioning from tracheostomy tube can influence the incidence of complications and determine patient's safety, possibility of recovery, the duration of treatment and the cost of treatment. It is critical for nurses to be aware of tracheostomy care recommendations based on scientific research and to apply them in clinical practice.

Aim of this research was to analyze nurses' knowledge and skills in technique of secretion suctioning from tracheostomy tube.

The research was conducted on 2013 year at the departments of Kaunas hospitals in which patients with tracheostomy are moved from Intensive Care departments. A questionnaire created by the authors of the research and an observation protocol of nurses' actions in practice was used to collect the data of the research. A survey was conducted with 93 nurses. We observed 99 procedures of secretion suctioning from tracheostomy tube. The research was conducted with the approval BEC-KS (M)-198 from the center of Bioethics of Lithuanian University of Health Sciences.

In clinical practice, the majority of nurses performed the action of suctioning from tracheostomy tube according to the need, did not pour a isotonic solution into tracheostomy tube. During the observation, the majority of nurses perform the suctioning action in the wrong sequence, about half of observed cases the suctioning action was prolonged and the pressure was too high. In clinical practice, while performing the action of suctioning from tracheostomy tube, nurses properly applied knowledge of the need of secretion suctioning from tracheostomy tube, the use of a isotonic solution. However, the majority of nurses did not apply the recommended sequence of actions of secretion suctioning, half of nurses - the recommended pressure and duration of suctioning.

Correspondence to: alina.vask@gmail.com

Gauta 2016-09-05 